\title{
XXXIX. Letter to Richard Taylor, Esq., as editor of the Philosophical Magazine and Journal
}

\section{Richard Potter Esq. B.A. F.C.P.S.}

To cite this article: Richard Potter Esq. B.A. F.C.P.S. (1840) XXXIX. Letter to Richard Taylor, Esq., as editor of the Philosophical Magazine and Journal , Philosophical Magazine Series 3, 16:102, 220-221, DOI: $10.1080 / 14786444008650023$

To link to this article: http://dx.doi.org/10.1080/14786444008650023

册 Published online: 01 Jun 2009.

Submit your article to this journal

Џ Article views: 2

Q View related articles $₫$ 
chlorine is passed be kept at a boiling heat, no crystals are formed, but a reddish oily fluid is produced; this, when analysed, was found to consist of

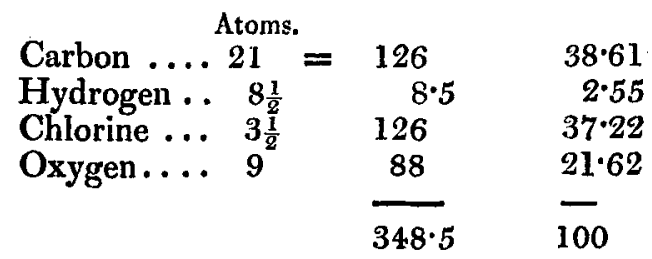

In this case, the anhydrous salicine loses $3 \frac{1}{2}$ atoms of hydrogen, and gains an equivalent proportion of chlorine. This new compound is soluble in alcohol and alkaline solutions.

G. B.

XXXIX. Letter to Richard Taylor, Esq., as Editor of the Philosophical Magazine and Journal. By R. Potter, Esq., B.A., F.C.P.S.

Dear Sir,

THE part you have taken in the controversy between Professor Forbes and myself has a good deal surprised me. That you should deprecate "personal imputations" in controversial papers, is what every reader of your periodical must heartily approve. However searching a review of Professor Forbes's "memorandum" was required for the defence of my own investigations, I congratulate myself on having avoided personalities or any imputation of unworthy motives. It is a philosophical and legitimate line of defence to inquire whether your opponent is a competent judge of the matter in controversy, from the consideration he has given to the subject, and whether he is to be considered in the light of an impartial and unbiassed inquirer, or otherwise whether he has imbibed theoretical views so deeply as to place him only in the situation of a partisan of the particular theory adopted by him. This course I have always endeavoured to pursue, and wonld cheerfully concede to an opponent. I think, however, that I have just reason to complain of the admission of such terms as "gratuitously misinterpreted," and " take a pleasure in misinterpreting my expressions," admitted in the very communication to which your note was appended.

In respect to the unsupported quotation from your unnamed correspondent's letter, which you have adopted, I have only to express my surprise that you did not suspect more than a filial solicitude for the Society's honour on his part. My notice of the proceedings of the Society to which I have the honour to belong, and amongst the leading members of 


\section{Mr. J. O. Halliwell's Note on the Boetian Contractions. 221}

which I have the honour to number so many scientific friends, conld arise from no other motive than a desire that its authority and pre-eminent position in the scientific world might be permanent and undiminished, by allowing no analytical essays relating to physical problems to be ushered forth under its auspices, until, in all practicable cases, their accordance with the involved physical facts was ascertained. The notice of one such essay in my former paper was sufficient to show that such had not always been the case. Your correspondent prudently preferred leaning on his influence with you, to challenging me to the proof of my assertion.

I have also to ask at your hands an explanation of the editorial censure contained in your note. I fully bow to your claim of right to moderate any expressions in communications which may be sent to you for publication. The advantage of a review by an impartial editor is great to all parties in a controversy, who in their excitement and sensibility naturally see a poignancy in the expressions of their opponents which they do not suspect in their own. On the other hand, I maintain that it is an unheard of proceeding in an editor who has published a paper without remark or private notice to the author, to pronounce a censure such as is contained in your note; and I claim from you this admission, which I think you will allow to be due under the circumstances.

$$
\text { Queen's College, February 4, 1840. Sir, yours truly, }
$$

In inserting $\mathrm{Mr}$. P's letter, we have only to state that the Editor's note was written in consequence of the remonstrance of the Member of the Cambridge Phil. Soc., and before the receipt of Prof. Forbes's letter, with which it had no connection; and was indeed intended to have occupied a distinct place in the Number.

We can assure Mr. Potter that his surmise respecting influence with us is unfounded; and willingly express our regret, that from having overlooked some portions of his communication, they should have become the subjects of public instead of private discussion.-R. T.

XI. Additional Note on the Authenticity of the disputed Passage in the treatise of Boetius de Geometria on Numerical Contractions. By J. O. HALLJweld, Esq., F.R.S., F.S.A., F.R.A.S., \&c.

I 'TRANSLATE the following extract from a letter which I have recently received from $M$. Chasles, because the view which he takes of this question is new, and his supporting arguments forcible:- " ln a passage found in some MSS. at the end of the second book of Boetius, the expression mensa geometricalia occurs; and this calculus is mentioned as ha. 